Agro Ekonomi Vol. 27/No. 1, Juni 2016

\title{
PERAN SEKTOR PERTANIAN DALAM MENGURANGI KETIMPANGAN PENDAPATAN DI WILAYAH PAPUA SEBELUM DAN SESUDAH OTONOMI KHUSUS
}

\author{
The Role of Agricultural Sector in Reducing Income Disparity in Papua Region Before \\ and After Special Autonomy \\ ${ }^{1}$ Siti Halimatus Sa'diyah dan ${ }^{2}$ Irham \\ ${ }^{1}$ Fakultas Pertanian Universitas Negeri Papua \\ ${ }^{2}$ Program Studi Ekonomi Pertanian, Universitas Gadjah Mada \\ ${ }^{2}$ Jalan Flora, Bulaksumur, Yogyakarta 55281 \\ halimatus2505@gmail.com
}

Diterima tanggal : 2 Februari 2016 ; Disetujui tanggal : 7 Maret 2016

\begin{abstract}
This study aims to determine: (i) the contribution of agriculture sector to GDP growth in the region before and after the Papua special autonomy, (ii) the level of income inequality per capita in the region before and after the Papua special autonomy, (iii) the role of agriculture in reducing income inequality in the community before and after the region Papua special autonomy, and (iv) the effect of investment, labor force, the allocation of funds for regional development, agglomeration in the region Papua, and policy implementation of special autonomy to Papua region against income inequality.Data used in this research is secondary data from the years 1993-2013 and analyzed using analysis of contribution, growth, income inequality (Williamson index, and multiple linear regression with OLS method. The analysis showed that the agricultural sectors contribution to GDP growth before special autonomy greater than after the special autonomy. Furthermore, per capita income inequality between regions in Papua special autonomy after the bigger (more unequal). The agricultural sector play a greater role in reducing income inequality communities in Papua after special autonomy than before the special autonomy. Investment in Papua per capita, regional development aid funds allocated per capita, and agglomeration in Papua positive effect on income inequality between regions in Papua. Index of income inequality between regions in Papua after special autonomy (the period 2002-2013) is greater than before the special autonomy (the period 1993-2001)
\end{abstract}

Keywords: agriculture, contribution, growth, GDP, income inequality

\section{INTISARI}

Provinsi Papua sudah menjalankan ontonomi khusus sejak pemerintah pusat mengesahkan Undang-Undang no.21 Tahun 2001 yang saat ini diganti dengan Undang-undang no. 35 Tahun 2008 perihal otonomi khusus untuk Papua dan Papua Barat. Otonomi ini menjadikan dua daerah tersebut memiliki kekuasaan yang lebih besar untuk mengatur dan mengorganisir wilayahnya tetapi masih berpegang pada prinsip pokok NKRI. Penelitian ini bertujuan untuk 
mengetahui: (I) kontribusi sektor pertanian terhadap pertumbuhan GDP di wilayah Papua, (II) tingkat ketidakmerataan pendapatan per capita, (III) peran sektor pertanian dalam mengurangi kesenjangan pendapatan, dan (IV) efek investasi,, angkatan kerja, alokasi pendanaan untuk pembangunan daerah, aglomerasi, dan kebijakan implementasi dari otonomi khusus di wilayah Papua tekait ketimpangan pendapatan. Tujuan-tujuan tersebut membandingkan antara sebelum dan sesudah pelaksanaan otonomi khusus. Data yang digunakan dalam penelitian ini adalah data sekunder dari tahun 1993 - 2013 dan dianalisis dengan pendekatan konstribusi, pertumbuhan, ketimpangan pendapatan (Williamson index dan Regresi berganda dengan metode OLS). Hasil analisis menunjukkan bahwa kontribusi sektor pertanian per capita terhadap pertumbuhan GDP sebelum otonomi lebih besar daripada saat sesudah otonomi dilaksanakan. Kemudian, ketimpangan pendapatan per kapita antar wilayah di Papua lebih besar setelah penerapan otonomi khusus. Sektor Pertanian memainkan peran yang lebih besar dalam mengurangi ketimpangan pendapatan di Papua setelah adanya otonomi khusus. Investasi per capita, alokasi bantuan dana untuk pembangunan daerah, dan aglomerasi di Papua memiliki efek yang positif terhadap kesenjangan pendapatan antar wilayah di papua. Indeks ketimpangan pendapatan lebih besar saat ada otonomi khusus dibanding sebelumnya.

Kata kunci: GDP, ketimpangan pendapatan, kontribusi, pertanian, pertumbuhan

\section{PENDAHULUAN}

Otonomi daerah merupakan salah satu kebijakan dan menjadi salah satu agenda reformasi, digunakan untuk meredam berbagai gejolak yang diakibatkan oleh ketimpangan pembangunan antar daerah. Otonomi daerah bukan konsep baru di Indonesia. Pemerintah pernah memberlakukan UU RI No. 5 Tahun 1974 tentang pokok-pokok pemerintahan di daerah. Kuncoro (2004) dalam Barika (2012) menyebutkan Indonesia telah bergerak dari negara sentralistik menjadi negara desentralisasi secara signifikan sejak tahun 2001 dengan mulai menerapkan UU No. 22 Tahun 1999 yang kemudian diganti dengan UU No. 32 Tahun 2004 dan diganti dengan UU No. 12 Tahun 2008 tentang Pemerintahan Daerah yang dikenal sebagai Undang-Undang Otonomi Daerah. Dalam penerapannya, undang-undang tersebut diiringi dengan pemberlakukan UU No. 25 Tahun 1999 tentang Perimbangan Keuangan antara Pemerintah Pusat dan Daerah dan diganti dengan UU No. 33 Tahun 2004.

Provinsi Papua mulai memberlakukan otonomi daerah secara khusus sejak pemerintah pusat secara resmi mengimlementasikan UU No. 21 Tahun 2001 dan saat ini dirubah dengan UU No. 35 Tahun 2008 tentang Otonomi Khusus Provinsi Papua dan Papua Barat (wilayah Papua). Secara ideal, pemberian Otonomi Khusus diharapkan dapat mengakomodasi kekhasan budaya dan adat istiadat masyarakat Papua, baik dalam pengelolaan pemerintahan maupun pembangunan di wilayah Papua dengan tujuan untuk mewujudkan keadilan, penegakan supremasi hukum, percepatan 
pembangunan ekonomi, peningkatan kesejahteraan masyarakat Papua yang dalam proses pembangunan sebelumnya masih jauh tertinggal jika dibandingkan dengan daerah lain di Indonesia.

Sampai saat ini, perekonomian di wilayah Papua masih didominasi dari sektor pertambangan dan penggalian (sebelum otonomi khusus kontribusi terhadap PDRB sebesar $46,77 \%$ dan setelah otonomi khusus meningkat menjadi 69,29\%), namun terjadi sebaliknya pada sektor pertanian yang sebelum otonomi khusus mampu berkontribusi terhadap PDRB sebesar 20,51\% dan setelah otonomi khusus justru terlihat mengalami penurunan $(13,10 \%)$. Fakta lain juga menunjukkan bahwa setiap kabupaten/ daerah tingkat II di wilayah Papua tidak memiliki potensi sumber daya yang merata, baik dari populasi penduduk dan sumber daya alamnya. Dengan demikian, maka pemerintah harus memberikan perhatian yang serius bagi sektor pertanian yang merupakan salah satu sektor yang menampung sebagian besar kebutuhan primer dan banyaknya jumlah masyarakat yang menggantungkan hidupnya pada sektor pertanian. Berkembangnya sektor pertanian diharapkan secara langsung dapat meningkatkan sekaligus pemerataan pendapatan dapat terjadi.

Tujuan yang hendak dicapai dari penelitian ini adalah untuk mengetahui: (i) besarnya sumbangan sektor pertanian terhadap pertumbuhan PDRB di wilayah Papua sebelum dan sesudah otonomi khusus (otsus), (ii) besarnya tingkat ketimpangan pendapatan per kapita di wilayah Papua sebelum dan sesudah otsus, (iii) peran sektor pertanian dalam mengurangi ketimpangan pendapatan masyarakat di wilayah Papua sebelum dan sesudah otsus, dan (iv) pengaruh investasi, angkatan kerja, alokasi dana bantuan pembangunan daerah, aglomerasi, dan kebijakan penerapan otonomi khusus terhadap ketimpangan pendapatan di Wilayah Papua

\section{Pembangunan Ekonomi}

Pembangunan merupakan suatu rangkaian proses perubahan menuju keadaan yang lebih baik dalam upaya meningkatkan kesejahteraan melalui peningkatan taraf hidup masyarakat yang diukur dengan peningkatan laju pertumbuhan ekonomi (Sari dkk, 2016). Pembangunan ekonomi mampu meningkatkan pendapatan per kapita penduduk dalam jangka panjang apabila dapat dilakukan dengan baik dan secara berkelanjutan. Hal ini disebabkan pelaksanaan pembangunan ekonomi mampu mendorong pertumbuhan ekonomi dan meningkatkan distribusi pendapatan bagi masyarakat (Bantika, 2015).

Pembangunan ekonomi seringkali diukur dengan tinggi-rendahnya pendapatan riil perkapita. Jadi, tujuan pembangunan ekonomi disamping untuk meningkatkan pendapatan nasional juga untuk meningkatkan produktivitas. Selain melalui pendapatan riil per kapita, hal 
lain yang mampu menjadi tolak ukur pembangunan adalah pertumbuhan ekonomi dan ukuran ketimpangan antar penduduk, antar daerah dan antar sektor (Kurniasih, 2013). Pembangunan ekonomi dipengaruhi oleh dua (2) faktor yaitu faktor ekonomi (SDA, SDM, Pembentukan modal dan teknologi) dan faktor non ekonomi (politik, sosial, budaya dan kebiasaan).

\section{Teori Pertumbuhan Ekonomi}

Pertumbuhan ekonomi didefinisikan sebagai perkembangan kegiatan ekonomi dari waktu ke waktu yang mampu meningkatkan pendapatan nasional (Sukirno, 2004 dalam Nurpita, 2016).

Menurut pandangan ahli-ahli ekonomi klasik seperti Thomas Robert Malthus, Adam Smith, David Ricardo dan John Stuart Mill, ada 4 faktor yang mempengaruhi pertumbuhan ekonomi yaitu jumlah penduduk, jumlah stok barang-barang modal, luas tanah dan kekayaan alam serta tingkat teknologi yang digunakan (Sukirno,1985). Selanjutnya Tambunan, (2003) bahwa pola pertumbuhan digunakan dalam teori dinamis sebagaimana dikembangkan oleh pemikir neo klasik. Dikemukakan bahwa pertumbuhan ekonomi berpokok pada efek investasi dan penambahan jumlah tenaga kerja terhadap pertumbuhan output serta proses peningkatan produksi barang dan jasa dalam kegiatan ekonomi masyarakat, dan tingkat pertumbuhan ekonomi harus lebih besar daripada laju pertumbuhan penduduk, agar peningkatan pendapatan perkapita dapat tercapai.

Menurut Kusdiana (2007: 11), pembangunan daerah merupakan suatu sinergi anatara pemerintah daerah dan masyarakat untuk mengelola potensi yang ada.

Menurut Ernita, Syamsul Amar, dan Efrizal Syofyan (2013) secara teori, pertumbuhan ekonomi yang ditopang oleh konsumsi tidak akan menjadi pertumbuhan yang berkelanjutan. Pertumbuhan ekonomi yang berkelanjutan adalah pertumbuhan yang ditopang oleh investasi. Pertumbuhan yang ditopang oleh investasi dianggap akan dapat meningkatkan produktivitas sehingga membantu meningkatkan pertumbuhan ekonomi.

\section{Pembangunan Ekonomi Daerah}

Arsyad (1997) membedakan pengertian daerah berdasarkan aspek ekonomi kedalam 3 kategori yaitu: (i) daerah homogen yakni daerah dianggap sebagai suatu ruang dimana kegiatan ekonomi terjadi dan didalam ruangan tersebut terdapat sifat-sifat yang sama. Kesamaan itu antara lain dari segi pendapatan perkapita, sosial budaya, geografis dan lain sebagainya; (ii) daerah nodal, yakni suatu daerah di anggap sebagai ekonomi ruang yang dikuasai oleh satu atau beberapa pusat kegiatan, dan (iii) daerah administratif, yakni suatu ekonomi ruang 
yang berada dibawah satu administratif tertentu, seperti satu provinsi, kabupaten, dan sebagainya.

Pembangunan ekonomi dalam jangka panjang mampu menyebabkan adanya rangkaian perubahan mendasar pada struktur ekonomi. Menurut Chenery dan Syrquin (1975) dalam Nazara (2010), terdapat empat proses yang terjadi bersamaan dalam perubahan struktural akibat adanya pembangunan ekonomi, antara lain proses akumulasi, proses alokasi, transisi kependudukan dan proses distribusi.

Pembangunan ekonomi daerah merupakan suatu proses dimana pemerintah daerah dan masyarakatnya mengelola sumberdaya yang ada dan membentuk suatu pola kemitraan untuk menciptakan suatu lapangan kerja baru dan merangsang perkembangan kegiatan ekonomi dalam wilayah tersebut yang pada dasarnya mencakup semua kegiatan pembangunan sektoral, regional, yang berlangsung di daerah.

Terdapat beberapa teori lain yang secara parsial dapat digunakan untuk memahami arti pentingnya pembangunan ekonomi daerah. Berkaitan dengan pembangunan daerah, Nazara (1994) mengungkapkan bahwa kebijaksanaan daerah harus mengarah pada dua sasaran pokok. Pertama, sasaran u $\mathrm{mu} \mathrm{m}$ ya $\mathrm{g}$ mi rip de nga n ke bijaka n nasional berupa pertumbuhan, pemerataan dan stabilitas. Kedua adalah perincian dari sasaran pertama yang diperhitungkan aspek spasial perekonomian seperti efisiensi lokal, masalah migrasi, pendapatan per kapita antardaerah, dan sebagainya.

\section{Ketimpangan Wilayah}

Pertumbuhan ekonomi yang dilakukan untuk meningkatkan kesejahteraan masyarakat seringkali berlangsung dengan cepat namun tidak diimbangi dengan pemerataan. Hal ini akan menimbulkan ketimpangan wilayah karena munculnya pembagian antara wilayah maju dan wilayah terbelakang (Nurhuda dkk, 2013). Ketimpangan pendapatan dapat terjadi antar individu, sektor, maupun daerah. Ketimpangan pendapatan di setiap daerah disebabkan perbedaan komposisi jumlah penduduk, sumber daya yang ada dan karakteristik setiap daerah. Ketimpangan tidak bisa dibiarkan tinggi karena dapat berdampak buruk terhadap kestabilan ekonomi dan politik (Daryanto dalam Amrillah dan Yasa, 2013).

Hal lain yang turut menyebabkan semakin terjadinya ketimpangan adalah daerah tertinggal tidak dapat mengalami kemajuan karena kurangnya sumberdaya yang dimiliki sehingga investor tidak memiliki kecenderungan untuk memilih daerah tersebut dalam melakukan pembangunan. Investor akan cenderung memilih daerah yang memiliki sarana prasarana yang lengkap seperti jaringan listrik, telekomunikasi, perbankan, asuransi dan sumberdaya manusia yang terampil (Barika, 2012). 
Hasil penelitian Nurhuda dkk (2013) menunjukkan PAD yang semakin besar dan merata pada daerah Provinsi Jawa Timur akan mendorong terjadinya peningkatan pertumbuhan ekonomi sehingga akan menurunkan tingkat ketimpangan pembangunan antar daerah. Selain itu, IPM yang semakin tinggi dan merata pada daerah Provinsi Jawa Timur akan mendorong terjadinya peningkatan pertumbuhan ekonomi sehingga akan menurunkan tingkat ketimpangan pembangunan antar daerah.

\section{METODE PENELITIAN}

\section{Jenis dan Sumber Data}

Jenis data yang akan adalah data sekunder (time series) dari tahun 19932013 yang meliputi PDRB kabupaten/ kota menurut lapangan usaha yang ada di wilayah Papua atas dasar harga konstan tahun 1993 dan tahun 2000; jumlah penduduk menurut kabupaten/ kota, data investasi, data angkatan kerja, dan alokasi dana bantuan pembangunan. Data diperoleh dari berbagai pihak antara lain: BPS, Dinas Pertanian Papua, PKPMD, laporan penelitian, jurnal, dan teori dari buku-buku yang berkaitan dengan masalah yang diteliti melalui studi pustaka.

\section{Metode Analisis Analisis Sumbangan Sektor Pertanian Terhadap PDRB}

Sumbangan sektor pertanian dihitung dengan rumus (BPS, 2004):

$$
P_{t i}=\frac{S_{t i}}{T_{t}} \times 100 \%
$$

dimana:

$\mathrm{P}_{\mathrm{ti}}=$ besarnya kontribusi sektor $\mathrm{i}$ pada tahun $\mathrm{t}(\%) ; \mathrm{S}_{\mathrm{ti}}=$ PDRB sektor $\mathrm{i}$ pada tahun $\mathrm{t}$ (rupiah); $\mathrm{T}_{\mathrm{t}}=$ total PDRB pada tahun $t$ (rupiah)

Kemudian dihitung besarnya pertumbuhan sektor yang dicapai selama jangka waktu tertentu dengan menggunakan rumus (Tambunan, 2003) :

dimana:

$$
G_{t i}=\frac{P_{t i}-P_{t i-1}}{P_{t i-1}} \times 100 \%
$$

$\mathrm{G}_{\mathrm{ti}}=$ besarnya pertumbuhan sektor $\mathrm{i}$

pada tahun $\mathrm{t}(\%) ; \mathrm{P}_{\mathrm{ti}}=$ PDRBsektor $\mathrm{i}$

pada tahun $\mathrm{t}$ (rupiah);

$\mathrm{P}_{\mathrm{t}-\mathrm{I}}=$ total PDRB sektor i pada tahun $\mathrm{t}-1$

(rupiah)

Perumusan Hipotesis 1:

$$
\begin{aligned}
\mathrm{H}_{0} \quad \text { : } & \text { Sumbangan sektor pertanian } \\
& \text { terhadap pertumbu han PDRB } \\
& \text { setelah otsus lebih kecil dibanding } \\
& \text { sebelum otsus. } \\
\mathrm{H}_{1} \quad: \quad & \text { Sumbangan sektor pertanian } \\
& \text { terhad ap pertumbu han PDRB } \\
& \text { setelah otsus lebih besar dibanding } \\
& \text { sebelum otsus. }
\end{aligned}
$$

\section{Analisis Ketimpangan Pendapatan}

Pengukuran ketimpangan pendapatan antar daerah di wilayah Papua dilakukan dengan menggunakan metode $\mathrm{CV}_{\mathrm{w}}$ dengan rumus (Syafrizal, 200) : 


$$
C V_{W}=\frac{\sqrt{\sum_{i}^{\mathrm{n}\left(Y_{i}-\grave{Y}\right)^{2} f i / n}}}{\grave{Y}}, 0<\mathrm{CVW}<1
$$

dimana :

$\mathrm{CV}_{\mathrm{w}}=$ Indeks Williamson (ketimpangan daerah);

$\mathrm{fi}_{0}=$ Jumlah penduduk di daerah $\mathrm{i}$

$\mathrm{n} \quad=$ Penduduk total;

Yi = PDRB per kapita di daerah I;

$\grave{Y}=$ Rata-rata PDRB per kapita provinsi

Hasil pengukuran dari nilai Inde ks Williams on ditunjukkan oleh angka 0 sampai angka 1 atau $0<\mathrm{CVw}<1$. Jika indeks Williamson semakin mendekati angka 1 maka semakin melebar ketimpangan pembangunan ekonomi.

$\mathrm{H}_{0}$ : Ketimpangan pendapatan per kapita di wilayah Papua sebelum dan sesudah otsus besar.

$\mathrm{H}_{1}$ : Ketimpangan pendapatan per kapita di wilayah Papua sesudah otsus semakin kecil.

\section{Analisi s Ketimpan ga $n$ Pendapata $n$ tanpa Sektor Pertanian}

Untuk melihat peranan sektor pertanian terhadap ketimpangan pendapatan daerah dilakukan dengan cara menghitung ketimpangan pendapaan daerah tanpa memasukkan nilai PDRB sektor pertanian dalam perhitungan tersebut. Kemudian dibandingkan dengan besarnya tingkat ketimpangan dengan memasukkan PDRB sektor pertanian. Apabila hasil perhitungan tingkat ketimpangan semakin besar, maka artinya sektor pertanian berperan dalam mengurangi tingkat ketimpangan yang terjadi

Perumusan Hipotesis:

$\mathrm{H}_{0}$ : $\quad$ Sektor pertanian berperan lebih kecil dalam mengurangi ketimpangan pendapatan masyarakat di wilayah Papua setelah otsus daripada sebelum otsus.

$\mathrm{H}_{1}$ : Sektor pertanian berperan lebih besar dalam mengurangi ketimpangan pendapatan masyarakat di wilayah Papua setelah otsus daripada sebelum otsus.

\section{Analisis Ketimpangan Pendapatan}

Cara untuk memperoleh nilai dari variabel investasi per kapita, ratio angkatan kerja, maupun alokasi dana bantuan pembangunan perkapita di wilayah Papua, maka untuk masing-masing variable tersebut dihitung dengan rumus sebagai berikut:

a. Untuk mengukur variabel investasi per kapita digunakan rumus (Suseno, 1990)

$$
X_{1}=\frac{\sum I}{\sum P d}
$$

dimana :

$$
\begin{aligned}
\sum \mathrm{I}= & \text { Jumlah realisasi Investasi di } \\
& \text { wilayah Papua } \\
\sum \mathrm{Pd}= & \text { Jumlah penduduk di wilayah } \\
& \text { Papua }
\end{aligned}
$$


b. Untuk mengukur ratio angkatan kerja menggunakan rumus (Suseno, 1990)

$$
X_{2}=\frac{\sum A k}{\sum P d}
$$

dimana :

$\sum$ Dbt $=$ Jumlah Angkatan Kerja di wilayah Papua

$\sum \mathrm{Pd}=$ Jumlah Penduduk di wilayah

Papua

c. Untuk mengukur dana bantuan per kapita diukur dengan rumus (Suseno,1990)

dimana : $\quad X_{3}=\frac{\sum D b t}{\sum P d}$

$\Sigma$ Dbt $=$ Jumlah Realisasi Dana

Bantuan di wilayah Papua

$\Sigma$ Pd = Jumlah Penduduk di wilayah Papua

d. Untuk mengukur Aglomerasi diukur dengan rumus :

IndeksBalassa $(\mathrm{x} 4)=\left(\frac{\sum i j}{\sum j E i j}\right) /\left(\frac{\sum i E i j}{\sum i \sum j E i j}\right)$ dimana :

$\mathrm{X}_{4}=$ aglomerasi/indeks balassa;

$\mathrm{i}=$ Sektor;

$\mathrm{j} \quad=$ Wilayah;

$\mathrm{E} \quad=$ Tenaga Kerja

Pembilang dari indeks in menyajikan bagian wilayah dari total te naga kerja pada sektor tertentu .Semakin terpusat suatu industri, semakin besar indeks Balassa-nya. Untuk menguji faktor-faktor yang mempengaru hI ketimpangan pendapatan digun ak an analisis regresi berganda dengan metode OLS (Gujarati, 2006). Faktorfaktor yang diduga mempengaruhi $\mathrm{k}$ e t i mp a $\mathrm{n} g$ a $\mathrm{n}$ adalah investasi, angkatan kerja, alokasi dana bantuan pembangunan daerah, aglomerasi di wilayah Papua, dan kebijakan penerapan otsus wilayah Papua. Estimasi dengan persamaan regresi terhadap Indeks Ketimpangan Pembangunan (Willi amson) adalah sebagai berikut:

$$
\begin{aligned}
C V_{w}= & \alpha_{0}+\alpha_{1} X_{1 t}+\alpha_{2} X_{2 t}+\alpha_{3} X_{3 t}+ \\
& \alpha_{4} X_{4 t}+\alpha_{5} D_{t}+\mu_{t}
\end{aligned}
$$

dimana:

$\mathrm{CVw}=$ indeks Williamson wilayah Papua; $\mathrm{X}_{1}=$ investasi di wilayah Papua per

kapita (Rp/kapita)

$\mathrm{X}_{2}=$ ratio angkatan kerja di wilayah Papua (\%)

$\mathrm{X}_{3}=$ alokasi dana bantuan pembangunan daerah per kapita (Rp)

$\mathrm{X}_{4}=$ aglomerasi di wilayah Papua

$\mathrm{D}=$ variabel dummy penerapan otsus $(D=1$, setelah penerapan otsus; $D=0$ jika sebelum otsus)

$\alpha_{0}=$ konstanta

$\alpha_{1}, \alpha_{2}, \alpha_{3}, \alpha_{4}$, dan $\alpha_{5}=$ koefisien

masing- masing dari $\mathrm{X}_{1}, \mathrm{X}_{2}, \mathrm{X}_{3}, \mathrm{X}_{4}$ dan

$\mathrm{D}_{5}$

$\mathrm{t}=$ menunjukan time series (periode waktu)

$\mu \quad=$ faktor gangguan 
Pengujian dilakukan dalam bentuk hipotesis berikut :

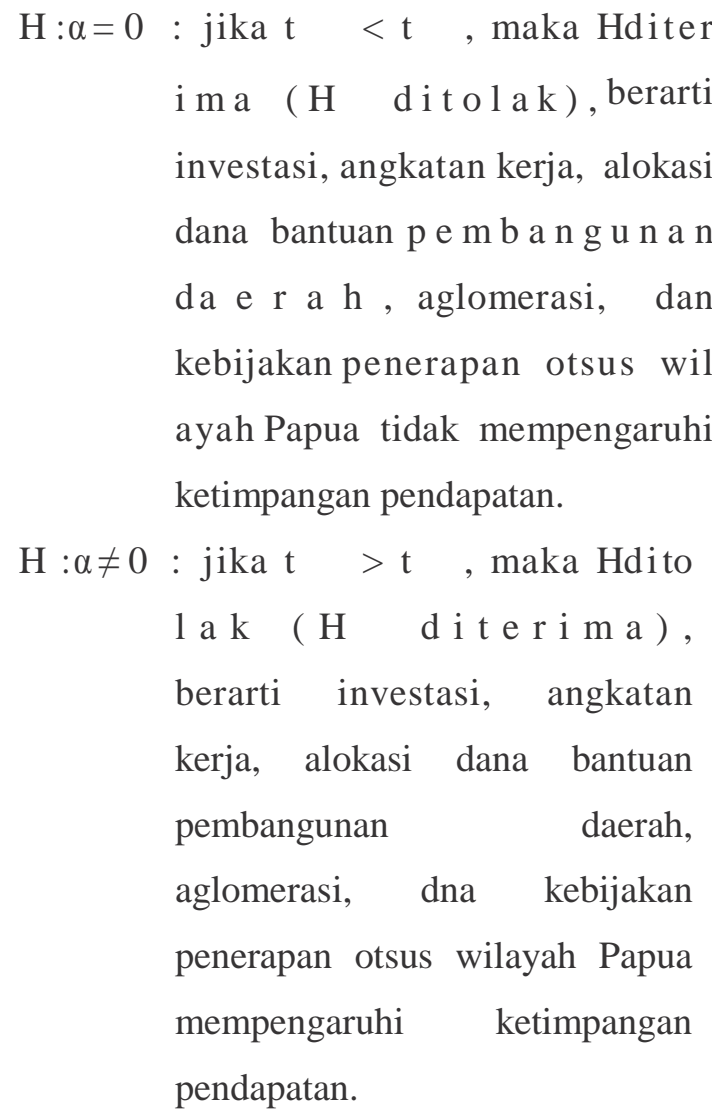

\section{HASIL DAN PEMBAHASAN}

\section{Sumbangan Sektor Pertanian Terhadap PDRB}

Sektor pertanian mempunyai peranan yang sangat penting dalam perkembangan perekonomian di wilayah Papua. Sektor ini memiliki kontribusi terbesar kedua setelah sector pertambangan dan penggalian dalam pembentukan PDRB selama periode tahun 1993-2013. Oleh karena itu fluktuasi nilai tambah dari kedua sector ini sangat berpengaruh terhadap total PDRB wilayah Papua. Khusus untuk sektor pertanian, kontribusi yang cukup besar utamanya berasal dari produksi tanama $\mathrm{n}$ bahan makanan yang mencapai $11,80 \%$ terhadap PDRB tahun 2013. Hasil penelitian memperlihatkan bahwa pada periode tahun 1993-2013 rata-rata sumbangan sektor pertanian terhadap pembentukan PDRB wilayah Papua sebesar 16,49\%. Rata-rata sumbangan sektor pertanian sebelum otsus (periode tahun 1993-2001) sebesar 17,53\% lebih besar daripada saat penerapan otsus (periode tahun 2002-2013) hanya 15,66\%.

Nilai PDRB selama periode tahun 1993-2013 memperlihatkan bahwa sektor pertanian tumbuh rata-rata $5,18 \%$ per tahun. Hasil penelitian menunjukkan b ahwa rata-rata pertumbuhan sektor pertanian dalam PDRB wilayah Papua sebelum otsus (periode tahun 1993-2001) adalah sebesar $6,37 \%$ lebih besar daripada setelah penerapan otsus (periode tahun 2002-2013) yakni sebesar 4,12\%.Hal ini mengindikasikan bahwa sektor pertanian $j$ ika dilihat dari kontribusi terhadap pembentukan PDRB wilayah Papua dan pertumbuhannya, setelah penerapan otsus justru mengalami perlambatan walaupun $t$ etap mengalami pertumbuhan yang positif, artinya sektor pertanian mengalami pertumbuhan yang lebih kecil dari sektor ekonomi lainnya dalam pembentukan PDRB wilayah Papua.

Untuk menguji hipotesis pertama dilakukan dengan uji t-test. Berdasarkan hasil analisis pada Tabel 1 menunjukkan 
Tabel 1. Sumbangan Sektor Pertanian Terhadap Pertumbuhan PDRB Sebelum dan Sesudah Otsus

\begin{tabular}{|c|c|c|c|c|c|}
\hline & Uraian & Perlakuan & Rata-rata & Perbedaan Rata-rata & t-hitung \\
\hline 1 & Sumbagan & $\begin{array}{l}\text { Sebelum otsus } \\
\text { Setelah otsus }\end{array}$ & $\begin{array}{l}17,53 \\
15,66\end{array}$ & 1,86 & $1,713^{*}$ \\
\hline 2 & Pertumbuhan & $\begin{array}{l}\text { Sebelum otsus } \\
\text { Setelah otsus }\end{array}$ & $\begin{array}{l}6,38 \\
4,12\end{array}$ & 2,25 & $1,052^{\mathrm{ns}}$ \\
\hline
\end{tabular}

Sumber: Data Sekunder, diolah

Keterangan: * = signifikan pada tingkat kepercayaan $90 \%$

ns $=$ non signifikan

bahwa sumbangan sektor pertanian terhadap pembentukan PDRB wilayah Papua secara statistik menunjukkan perbedaan yang signifikan pada tingkat kepercayaan $90 \%$ dimana sumbangan sektor pertanian sebelum otsus lebih besar dibandingkan dengan setelah penerapan otsus. Jika dilihat dari pertumbuhan sektor pertanian dalam PDRB secara statistik tidak menunjukkan adanya beda nyata (non signifikan) antara sebelum dan sesudah otsus. Hal ini menunjukkan bahwa pertumbuhan penerapan otsus di wilayah Papua belum memberikan dampak yang signifikan terhadap pertumbuhan sector pertanian.

Berdasarkan hasil analisis diatas pada memperlihatkan bahwa sumbangan sektor pertanian sebelum otsus rata-rata sebesar 17,53\% per tahun dan setelah otsus rata-rata sebesar $15,66 \%$ per tahun yang diikuti dengan tingkat pertumbuhan yang semakin menurun yakni dari $6,38 \%$ per tahun sebelum otsus turun menjadi $4,12 \%$ per tahun setelah otsus. Dengan demikian, hipotesis bahwa "diduga sumbangan sektor pertanian terhadap pertumbuhan PDRB

setelah otsus lebih besar dibanding sebelum otsus" tidak dapat diterima ( $\mathrm{H}$ ditolak) atau menerima $\mathrm{H}$ yaitu sumbangan sektor pertanian terhadap pertumbuhan PDRB setelah otsus lebih kecil dibanding sebelum otsus.

\section{Ketimpangan Pendapatan}

Pada awal pembangunan akan terjadi disparitas regional yang tinggi dan pembangunan hanya terpusat pada daerahdaerah tertentu sehingga biasanya pada tahap awal pertumbuhan ekonomi yang lebih maju maka keseimbangan antar daerah dan disparitas akan berkurang dengan signifikan. Untuk melihat pengaruh penerapan otsus di wilayah Papua terhadap pembangunan ekonomi di wilayah Papua. Salah satu model yang cukup representatif untuk mengukur tingkat ketimpangan pembangunan antar wilayah adalah indeks Williamson.

Hasil penelitian menunjukkan secara keseluruhan nilai indeks Williamson selama periode tahun 1993-2013 berfluktuasi dengan rata-rata 0,4038 namun cenderung meningkat. Rata-rata nilai ketimpangan 
Agro Ekonomi Vol. 27/No. 1, Juni 2016

11

pendapatan di wilayah Papua sebelum otsus (1993-2001) adalah sebesar 0,2476. Pada awal tahun penelitian (1993) nilai ketimpangan pendapatan sebesar 0,07 tahun 1994 meningkat menjadi 0,24 dan nilai indeks ketimpangan ini cenderung stabil sampai pada tahun 2000, namun pada tahun 2001 sebagai tahun awal penerapan otsus terlihat mengalami peningkatan yang cukup signifikan, yakni sebesar 0,64. Sedangkan pada awal tahun pelaksanaan otsus(2002) nilai indeks ketimpangan pendapatan adalah sebesar 0,66. Nilai indeks ketimpangan rata- rata setelah otsus lebih tinggi dibandingkan dengan sebelum ots us. Hal tersebut ditunjukkan pada Tabel 2.

Tabel 2. Nilai Ketimpangan Pendapatan Antar Daerah di Wilayah Papua Menurut Inde ks Williamson Sebelum dan Sesudah Otsus, Tahun 1993-2013

\begin{tabular}{lllll}
\hline No & Uraian & Rata-rata & $\begin{array}{c}\text { Perbedaan } \\
\text { Rata-rata }\end{array}$ & t-hitung \\
\hline 1. & $\begin{array}{l}\text { Sebelum } \\
\text { Otsus } \\
(1993-\end{array}$ & 0,2476 & & \\
& & & \\
$2001)$ & & & \\
2. & Setelah & 0,5209 & 0,2734 & $4,542^{* * *}$ \\
& $\begin{array}{l}\text { Otsus } \\
(2002-\end{array}$ \\
& & & \\
2013) & & & \\
\end{tabular}

Sumber: data sekunder, diolah

Keterangan: $\quad * * *=$ signifikan pada tingkat kepercayaan $95 \%$

$$
\mathrm{ns}=\text { non signifikan }
$$

Tabel 2 menunjukkan bahwa secara statistik terdapat perbedaan yang signifikan nilai indeks ketimpangan pendapatan antar daerah di wilayah Papua pada tingkat kepercayaan 95\%. Besarnya perbedaan nilai indeks ketimpangan pendapatan tersebut adalah sebesar 0,2734. Hal ini menunjukkan bahwa setelah otsus ketimpangan pendapatan antar daerah di wilayah Papua semakin timpang. Ketimpangan pendapatan antar daerah di wilayah Papua, tergantung dari besarnya jumlah pendapatan yang diterima oleh setiap penerima pendapatan dalam daerah tersebut, baik itu golongan masyarakat maup un wilayah tertentu. Perbedaan jumlah pendapatan yang diterima itu menimbulkan suatu distribusi pendapatan yang berbeda, sedangkan besar kecilnya perbadaan tersebut akan menentukan tingkat pemerataan pendapatan (ketimpangan pendapatan) daerah tersebut. Dengan demikian, ketimpangan pendapatan per kapita antar daerah di wilayah Papua sesudah otsus semakin besar sehingga hipotesis bahwa "diduga ketimpangan pendapatan per kapita di wilayah Papua sesudah otsus semakin kecil" tidak terbukti kebenarannya (H ditolak).

\section{Peran Sektor Pertanian Terhadap}

\section{Ketimpangan Pendapatan}

Hasil penelitian menunjukkan bahwa rata-rata nilai indeks ketimpangan pendapatan antar daerah di wilayah Papua tanpa memasukkan nilai PDRB sektor $p$ ertanian dalam perhitungan adalah sebesar 0,6626 dan dengan memasukkan PDRB sektor pertanian dalam perhitungan diperoleh nilai indeks ketimpangan 
sebesar 0,4085. Hal ini berarti bahwa dengan mengeluarkan sektor pertanian ketimpangan semakin besar. S e 1 a $\mathrm{n} \mathrm{j} \mathrm{u} \mathrm{t}$ ny a, nilai i nde ks ketimpangan pendapatan antar daerah di wilayah Papua sebelum otsus (1993-2001) tanpa memasukkan nilai PDRB sektor pertanian dalam perhitungan adalah sebesar

0,3130 dan setelah otsus (2002-2013) adalah sebesar 0,9081 sedangkan dengan memasukkan PDRB sektor pertanian dalam perhitungan diperoleh nilai indeks ketimpangan pendapatan antar daerah di wilayah Papua sebelum otsus (19932001) adalah sebesar 0,2587 dan setelah otsus (2002-2013) adalah sebesar 0,5209. Perhitungan ini memperlihatkan bahwa nilai indeks ketimpangan pendapatan antar daerah di wilayah Papua tanpa memasukkan nilai PDRB sektor pertanian lebih besar dibanding dengan nilai indeks ketimpangan pendapatan antar daerah di wilayah Papua dengan memasukkan nilai PDRB sektor pertanian. Hasil penelitian menunjukkan bahwa sektor pertanian selama periode tahun 1993-2013 sangat berperan dalam mengurangi ketimpangan pendapatan antar daerah di wilayah Papua. Nilai indeks ketimpangan pendapatan antar daerah di wilayah Papua dengan dan tanpa sektor pertanian sebelum dan sesudah otsus periode tahun 1993-2013 ditunjukkan Tabel 3.
Tabel 3. Nilai Indeks Ketimpangan Pendapatan Antar Daerah di Wilayah Papua Dengan dan Tanpa Sektor Pertanian Sebelum dan Sesudah Otsus, Tahun 19932013

Indeks Williamson

\begin{tabular}{clcc} 
No & \multicolumn{1}{c}{ Uraian } & \multicolumn{2}{c}{$\begin{array}{c}\text { Tanpa Sektor Dengan Sektor } \\
\text { Pertanian }\end{array}$} \\
& & Pertanian \\
\hline 1. & $\begin{array}{l}\text { Sebelum Otsus } \\
(1993-2001)\end{array}$ & 0,3130 & 0,2476 \\
2. & $\begin{array}{l}\text { Setelah Otsus } \\
(2002-2013)\end{array}$ & 0,9081 & 0,5209
\end{tabular}

Sumber: data sekunder, diolah

Pelaksanaan otsus di wilayah Papua diharapkan menjadi sebuah proses transformasi menuju terbentuknya keseimbangan, karena dengan status otsus diharapkan semakin meningkatkan tingkat kemandirian dan kemampuan daerah dalam mengelola pembangunan ekonomi daerahnya. Sektor pertanian di wilayah Papua perlu terus didorong sebagai penunjang yang positif terhadap pembangunan ekonomi di wilayah Papua. Hal tersebut dapat dicapai melalui strategi investasi dan kebijaksanaan pengembanan profesionalitas dan produktivitas tenaga kerja pertanian, pengembangan sarana dan prasarana ekonomi, pengembangan ilmu pengetahuan dan teknologi disertai dengan penataan dan pengembangan kelembagaan dan pedesaan. Melalui usaha tersebut maka, partisipasi aktif petani dan masyarakat pedesaan dapat ditingkatkan. Dengan demikian, hipotesis bahwa "diduga sektor 
Agro Ekonomi Vol. 27/No. 1, Juni 2016

pertanian berperan lebih besar dalam mengurangi ketimpangan pendapatan masyarakat di wilayah Papua setelah otsus daripada sebelum otsus" dapat diterima kebenarannya.

\section{Faktor-Faktor yang Mempengaruhi Ketimpangan Pendapatan}

Untuk mengestimasi fungsi faktorfaktor yang mempengaruhi ketimpangan pendapatan di wilayah Papua dengan model indeks Williamson dilakukan dengan analisis regresi linear berganda dengan metode OLS. Faktor-faktor yang diduga mempengaruhi ketimpangan pendapatan di wilayah Papua adalah investasi di wilayah Papua per kapita, angkatan kerja di wilayah Papua, alokasi dana bantuan pembangunan daerah per kapita, aglomerasi di wilayah Papua, dan kebijakan penerapan otsus wilayah Papua. Dari hasil analisis baik model indeks Williamson diperoleh persamaan ketimpangan pendapatan antar daerah di wilayah Papua yakni:

Model Indeks Williamson:

$\mathrm{CVW}_{\mathrm{W}}=0,7467-0,0087 \mathrm{X}_{1}+0,4303 \mathrm{X}_{2}-$ $2,5101 \mathrm{X}_{3}-0,9275 \mathrm{X}_{4}+0,4627 \mathrm{D}_{\mathrm{t}}+\mu_{\mathrm{t}}$

Hasil uji analisis faktor-faktor yang diduga mempengaruhi ketimpangan pendapatan di wilayah Papua untuk model indeks Williamson diperoleh nilai koefisien determinan $\left(\mathrm{R}^{2)}\right.$ sebesar 0,9498. Hal ini menunjukkan bahwa sekitar $94,98 \%$ variasi ketimpangan pendapatan dapat dijelaskan oleh investasi per kapita, angkatan kerja, alokasi dana bantuan pembangunan daerah per kapita, aglomerasi, dan kebijakan penerapan otsusdi wilayah Papua sementara sisanya $(5,02 \%)$ dijelaskan oleh variabel independen lain di luar model analisis yang digunakan.

Hasil penelitian menunjukkan bahwa sebesar 45,4033 dan nilai F-hitung tersebut jauh lebih besar dari nilai F-tabel yang ditunjukkan pada probabilitas F-hitung yang sangat rendah (probalilitas < 1\%). Hal ini menunjukkan bahwa variabel independen yaitu investasi, angkatan kerja, alokasi dana bantuan pembangunan daerah per kapita, aglomerasi, dan kebijakan penerapan otsus di wilayah Papua secara bersama-sama berpengaruh nyata terhadap ketimpangan pendapatan antar daerah di wilayah Papua pada tingkat kepercayaan 99\%. Dalam analisis empiris, baik atau buruknya model bukan saja dilihat dari besarnya nilai $\mathrm{R}^{2}$ yang diperolah akan tetapi juga harus melihat kesesuaian tanda koefisien regresi dengan teori ekonomi. Uraian mengenai faktorfaktor yang mempengaruhi ketimpangan pendapatan antar daerah di wilayah Papua yang terdapat pada model yang telah disusun sebagai berikut:

a. Investasi di wilayah Papua per kapita Variabel investasi di wilayah Papua per kapita secara statistik menunjukkan 
pengaruh yang signifikan dan negatif terhadap ketimpangan pendapatan antar daerah di wilayah Papua pada tingkat kepercayaan $99 \%$ dengan nilai koefisien regresi sebesar $-0,0088$. Hal ini berarti bahwa apabila nilai investasi di wilayah Papua per kapita meningkat 1 rupiah dengan asumsi faktor lain dalam keadaan tetap, maka ketimpangan pendapatan antar daerah di wilayah Papua mengalami penurunan 0,0088. Variabel investasi di wilayah Papua per kapita perlu ditingkatkan karena peningkatan nilai variabel ini dapat memberikan dampak positif terhadap peningkatan produksi lapangan kerja. Sumber investasi dapat berasal dari pemerintah maupun swasta.Untuk investasi swasta lebih banyak ditentukan oleh kekuatan pasar dimana keuntungan lokasi yang dimiliki oleh suatu daerah merupakan kekuatan yang berperan dalam menarik pelaku investasi Keuntungan lokasi ditentukan oleh biaya transpor baik bahan baku, perbedaan upah buruh, konsentrasi pasar, tingkat persaingan usaha dan sewa tanah. Kebijakan alokasi investasi regional menjadi penting bagi kabupaten/kota yang ada di wilayah Papua bila tujuan pembangunan wilayah yang ingin dicapai yaitu peningkatan pertumbuhan ekonomi dan pemerataan, karena dengan hal tersebut dapat ditentukan prioritasprioritas yang akan dilaksanakan.
Investasi berhubungan erat dengan pertumbuhan ekonomi suatu wilayah karena dengan semakin banyaknya investasi yang masuk ke dalam suatu wilayah akan meningkatkan output yang dihasilkan dan berakhir pada peningkatan pertumbuhan ekonomi. Akan tetapi investasi besar yang masuk ke suatu wilayah justru akan menyebabkan ketidakmerataan apabila dilakukan dengan system perencanaan yang kurang baik.

b. Ratio angkatan kerja di wilayah Papua Variabel ratio angkatan kerja di wilayah Papua baik dalam model indeks Williamson secara statistik tidak menunjukkan pengaruh yang nyata (non signifikan) terhadap indeks ketimpangan pendapatan antar daerah di wilayah Papua.Hal ini menunjukkan bahwa selama periode waktu penelitian variabel ratio angkatan kerja di wilayah Papua tidak memberikan pengaruh yang nyata terhadap perubahan nilai indeks ketimpangan pendapatan antar daerah di wilayah Papua. Tidak terlihatnya pengaruh dari variabel ratio angkatan kerja dapat disebabkan antara lain, rasio angkatan kerja di wilayah Papua sangat rendah dan kebanyakan bekerja pada sektor informal.

c. Alokasi dana bantuan pembangunan daerah per kapita 
Pemberian status otsus sejak tahun 2001

wilayah Papua memberi konsekuensi dana pembangunan atau pemerintah di wilayah Papua dari pemerintah pusat lebih besar. Diharapkan ketimpangan pembangunan antar wilayah akan menjadi lebih rendah. Hasil penelitian menunjukkan bahwa variabel alokasi dana bantuan pembangunan daerah per kapita secara statistik menunjukkan pengaruh yang signfikan dan negatif terhadap indeks ketimpangan pendapatan antar daerah di wilayah Papua pada tingkat kepercayaan 95\%. Besarnya nilai koefisien regresi dari variabel alokasi dana bantuan pembangunan daerah per kapita adalah sebesar -2,5101. Hal ini berarti bahwa apabila nilai variabel alokasi dana bantuan pembangunan daerah per kapita meningkat 1 rupiah dengan asumsi variabel lain dalam keadaan tetap maka nilai indeks ketimpangan pendapatan antar daerah di wilayah Papua mengalami penurunan sebesar 2,5101. Arah koefisien dari variabel ini secara teori adalah sesuai, bahwa dengan meningkatkan variabel alokasi dana bantuan pembangunan daerah per kapita berdampak secara positif terhadap penurunan nilai indeks ketimpangan pendapatan antar daerah di wilayah Papua. Variabel alokasi dana bantuan pembangunan daerah per kapita perlu terus ditingkatkan sesuai dengan kemampuan karena alokasi dana bantuan per kapita menandakan adanya pemerataan karena daerah mendapatkan dana berdasarkan jumlah penduduk yang ada di wilayah bersangkutan. Hasil penelitian sejalan dengan pendapat dari Nurmanah (1989), bahwa ketimpangan dan variasi distribusi pendapatan mempunyai hubungan yang positif dengan distribusi penguasaan faktorfaktor produksi sehingga perlu adanya campur tangan pemerintah pusat untuk mengurangi ketimpangan pembangunan antar daerah, misalnya dengan memberikan bantuan kepada daerah untuk mempercepat pembangunan daerah.

\section{d. Aglomerasi di wilayah Papua}

Variabel aglomerasi di wilayah Papua secara statistik berpengaruh nyata dan negatif terhadap nilai indeks ketimpangan pendapatan antar daerah di wilayah Papua pada tingkat kepercayaan 95\%. Besarnya nilai koefisien regresi dari variabel aglomerasi di wilayah Papua sebesar 0,9275. Tanda koefisien aglomerasi di wilayah Papua adalah negatif.Tanda koefisien tersebut sudah sesuai dengan teori ekonomi dan hipotesis yang diajukan dalam penelitian ini bahwa diduga aglomerasi di wilayah Papua berpengaruh secara positif terhadap indeks ketimpangan pendapatan antar daerah di wilayah Papua. Hal ini 
menunjukkan bahwa apabila variabel aglomerasi di wilayah Papua meningkat dengan asumsi faktor lain dalam keadaan tetap, maka nilai indeks ketimpangan pendapatan antar daerah di wilayah Papua mengalami penurunan sebesar nilai koefisien regresi dari variabel aglomerasi tersebut. Aglomerasi adalah konsentrasi spasial dari aktifitas ekonomi dikawasan perkotaan karena penghematan akibat dari perusahaan yang letaknya saling berdekatan dan tidak akibat dari kalkulasi perusahaan secara individual. Kekuatan aglomerasi dapat menjelaskan terjadinya konsentrasi dan dekonsentrasi industri yang ada di wilayah Papua sehingga variabel aglomerasi perlu mendapatkan perhatian dari pemerintahan mengingat pengaruh dari variabel ini berdampak secara negatif terhadap indeks ketimpangan pendapatan antar daerah. Artinya proses aglomerasi yang baik akan mengurangi ketimpangan pendapatan antar daerah di wilayah Papua. Hasil penelitian ini sesuai dengan pendapat dari Syafrizal (2008), bahwa aglomerasi yang cukup tinggi akan menyebabkan petumbuhan ekonomi daerah cenderung tumbuh lebih cepat. Kondisi tersebut akan mendorong proses pembangunan daerah melalui peningkatan penyediaan lapangan kerja dan tingkat pendapatan masyarakat. Namun bagi daerah yang memiliki tingkat aglomerasi yang rendah akan membuat daerah tersebut semakin terbelakang.

e. Kebijakan Otonomi Khusus

Hasil penelitian menunjukkan bahwa kebijakan otsus secara statistik menunjukkan pengaruh yang signifikan terhadap nilai indeks ketimpangan pendapatan antar daerah di wilayah Papua pada tingkat kepercayaan 99\%. Hal ini menunjukkan bahwa terdapat perbedaan yang signifikan terhadap nilai indeks ketimpangan pendapatan antar daerah di wilayah Papua dimana nilai indeks ketimpangan sebelum otsus (1993-2001) lebih rendah dibandingkan dengan sesudah otsus (2002-2013) atau dengan kata lain adanya kebijakan pemberian otsus di wilayah Papua tersebut justru semakin memperbesar nilai indeks ketimpangan pendapatan antar daerah di wilayah Papua. Dari model indeks Williamson diperoleh nilai koefisien regresi sebesar 0,4627 Besarnya nilai koefisien regresi tersebut menunjukkan besarnya nilai perbedaan indeks ketimpangan pendapatan antar daerah di wilayah Papua sebelum otsus (19932001) dan sesudah otsus (2002-2013). Nilai koefisien regresi yang bernilai positif tersebut merupakan suatu konsekuensi dari suatu proses awal pembangunan di suatu wilayah bahwa biasanya diawal pembangunan ekonomi suatu daerah akan menyebabkan ketidak merataan akan tetapi dalam jangka 
panjang diharapkan hasil pembangunan tersebut terjadi pemerataan antar daerah di wilayah Papua. Pemberlakuan UU No. 21 Tahun 2001, kesempatan daerah untuk berkreasi dalam upaya meningkatkan pelaksanaan pembangunan di wilayah Papua berdasarkan karakteristik yang dimiliki semakin besar. Oleh karena itu, harus dapat dipastikan bahwa sistem perencanaan pembangunan antar daerah di wilayah Papua akan cenderung berbeda seperti dalam hal pengurangan tingkat kemiskinan, peningkatan kesempatan kerja, perbaikan kesejahteraan dan sekaligus untuk mengurangi tingkat kesenjangan ekonomi, baik antar kelompok masyarakat maupun antar wilayah.

\section{KESIMPULAN DAN SARAN}

\section{Kesimpulan}

1. Sumbangan sektor pertanian terhadap pertumbuhan PDRB sebelum otsus lebih besar dibanding setelah otsus.

2. Ketimpangan pendapatan per kapita antar daerah di wilayah Papua sesudah otsus semakin besar (semakin timpang).

3. Sektor pertanian berperan lebih besar dalam mengurangi ketimpangan pendapatan masyarakat di wilayah Papua setelah otsus daripada sebelum otsus.

4. Investasi di wilayah Papua per kapita, alokasi dana bantuan pembangunan daerah per kapita, dan aglomerasi di wilayah Papua berpengaruh secara positif terhadap ketimpangan pendapatan antar daerah di wilayah Papua.Indeks ketimpangan pendapatan antar daerah di wilayah Papua setelah otsus (2002-2013) lebih besar dibanding dengan sebelum otsus (1993-2001).

\section{Saran}

Untuk mengurangi ketimpangan maka Pemerintah Provinsi Papua perlu meningkatkan investasi ke daerah baik melalui dana alokasi khusus maupun menggunakan dana swasta. Pemerintah juga perlu mengevaluasi otonomi khusus untuk merencanakan strategi pembangunan yang mampu mengurangi ketimpangan pendapatan.

\section{DAFTAR PUSTAKA}

Amrillah dan I. N Mahendra Yasa. 2013. Analisis Disparitas Pendapatan Per kapita antar Kecamatan dan Potensi Pertumbuhan Ekonomi Kecamatan di Kabupaten Karangasem. EJurnal Ekonomi Pembangunan Universitas Udayana Vol. 2, No. 4 181-189.

Badan Pusat Statistik. Papua dalam Angka Berbagai Tahun Terbitan. Jayapura: BPS Provinsi Papua.

Bantika, V. 2015. Faktor-Faktor yang Mempengaruhi Ketimpangan Distribusi Pendapatan di Sulawesi Utara. Jurnal Unsrat. Vol. 6, No. 17.

Barika, 2012. Analisis Ketimpangan Pembangunan Wilayah Kabupaten/Kota di Provinsi Bengkulu Tahun 2005-2009. Jurnal Ekonomi dan Perencanaan Pembangunan. Vol IV (3) : 1-11 
Boediono,. 1992. Teori Pertumbuhan Ekonomi. BPFE-Yogyakarta. Yogyakarta

Gujarati. Damodar. 2006 Dasar-Dasar Ekonometrika Jilid 1\& II .Penerbit Erlangga.Jakarta

Kurniasih, Erni Panca. 2013. Ketimpangan Wilayah di Provinsi Kalimantan Barat Suatu Kajian terhadap Hipotesis Kuznet. Jurnal Eksos. Vol. 9, No. $1: 36-48$.

Kusdiana, Didik dan Candra Wulan. 2007. Analisis Daya Saing Ekspor Sektor Unggulan di Jawa Barat. Junal Trikonomika Fakultas Ekonomi Unpas Vol 6 No. 1 Juni 2007

Nazara, Suahasil. 2010. Pemerataan Antardaerah sebagai Tantangan Utama Transformasi Struktural Pembangunan Ekonomi Indonesia Masa Depan. Jurnal Ekonomi dan Pembangunan Indonesia. Vol. 11, No. $1: 83-98$.

Nurhuda, R., M. R. Khairul Muluk dan W Y. Prasetyo. 2013. Analisis Ketimpangan Pembangunan (Studi di Provinsi Jawa Timur Tahun 2005-2011) Jurnal Administrasi Publik. Vol 1 (4) : 110-119|118

Nurpita, Anisa. 2016. The Analysis of Development Disparities Inter District/City in Special Region of Yogyakarta (DIY) Province 20032013. Jurnal Kebijakan dan Administrasi Publik. Vol. 20, No. 1: 23-37.

Sari, G.N., P. Kindangen, R.O. Rotinsulu. 2016. Pengaruh Kinerja Keuangan Terhadap Pertumbuhan Ekonomi Perkotaan di Sulawesi Utara Tahun 2004-2014. Jurnal Pembangunan Ekonomi dan Keuangan Daerah. Vol 18, No. 2.

Soepono. P, 1993. Teori Pertumbuhan Berbasis Ekonomi (Ekspor): Posisi dan Sumbangannya bagi Perbendaharaan Alat-Alat Analisis Regional, Jurnal Ekonomi dan Bisnis Indonesia. Vol. 16, No. 1.

Tambunan, T. 2003. Perekonomian Indonesia: Beberapa Masalah Penting. Ghalia Indonesia. Jakarta 